\title{
Post-Harvest Quality of cv. Markies Potatoes Submited to Mechancial Damages
}

\author{
Dreice Nascimento Gonçalves ${ }^{1}$, Ariana Mota Pereira ${ }^{1}$, Luciana Gomes Soares ${ }^{1}$, \\ Maria Eduarda da Silva Guimarães ${ }^{1}$, Kharen Priscilla de Oliveira Salomão Petrucci ${ }^{1}$, Lucilene Silva de Oliveira , \\ Abelardo Barreto de Mendonça Neto ${ }^{1} \&$ Fernando Luiz Finger ${ }^{1}$ \\ ${ }^{1}$ Universidade Federal de Viçosa, Viçosa, MG, Brazil \\ Correspondence: Ariana Mota Pereira, Universidade Federal de Viçosa, P.h. Rolf, Campus Universitário, CEP \\ 36570-900, Viçosa, MG, Brazil. E-mail: ariana.mota@ufv.br
}

Received: July 1, 2019

doi:10.5539/jas.v12n2p124
Accepted: December 4, 2019 Online Published: January 15, 2020

URL: https://doi.org/10.5539/jas.v12n2p124

\begin{abstract}
Mechanical damage and storage conditions may alter carbohydrate metabolism and oxidative enzyme activity, causing darkening and impairing the use of tubers in pre-fried potato processing industry. The objective of this study was to evaluate the enzymatic changes and carbohydrate metabolism of 'Markies' potato tubers subjected to mechanical damage and exposed to high temperatures before processing. The tubers were stored for 4 months at $8{ }^{\circ} \mathrm{C}$, and further divided into treatment with impact and abrasion damage; and control treatment, in which the tubers were not damaged. Afterwards, they were stored at $28{ }^{\circ} \mathrm{C}$ room temperature, evaluated for loss of accumulated fresh mass (FML); total soluble sugar (TSS), reducing sugar (RS) and non-reducing sugar (NRS); color after frying and activity of polyphenoloxidase (PPO) and peroxidase (POD) at 0, 12, 24, 36 and $48 \mathrm{~h}$ after placed at room temperature. The mechanical damages incremented FML, RS, PPO and TSS, NRS and POD up to $35.6,34$, and $22 \mathrm{~h}$, respectively. Regardless of the occurrence of mechanical damage and the period of evaluation, the sticks showed a light color after frying and were classified in category 2 . The increase in the evaluation time led to the rise in FML and the PPO activity. It is concluded that the mechanical damages increase the FML and cause darkening of the tips of the sticks after frying, however this variety still display qualities that are suitable for industrial processing.
\end{abstract}

Keywords: color, peroxidase, polyphenoloxidase, reducing sugar

\section{Introduction}

For the autonomy of the processing industry, it is necessary to use cultivars of adequate shape and size and lack of physiological disturbances besides a high content of soluble solids, dry mass and light coloring after frying (Keijbets, 2008). Cultivar 'Markies' meets these requirements, possessing culinary ability for cooking and frying.

Potato (Solanum tuberosum L.) is the third most important and consumed crop in the world (Wang et al., 2015). The consumption of processed potatoes has been increasing as a result of the changes in diets, the increase in fast food chains and the need for semi-finished foods. To meet the processed potato market, it is necessary to cultivate the land and the refrigeration industry for quality maintenance and constant supply.

Refrigerated storage is performed to maintain the quality of the potatoes by reducing respiration and inhibiting sprouting, and for constant supply to the industry. However, over the cold chamber unloading and post-harvest handling process, tubers are subject to mechanical damage caused by impact, compression, vibration, cuts and cracks, inducing a series of physiological responses which results in the reduction in the quality.

In addition to the stress promoted by the damage, from the storage and processing stages, the tubers can stay for approximately 48 hours at room temperature, which contributes to the increase in loss of the quality.

The quality of tubers is mainly associated with light color. The darkening may be of non-enzymatic and enzymatic origin. Non-enzymatic darkening occurs due to the increase in the contents of sugars induced by refrigerated storage. Through the Maillard reaction, sugars react with amino acids, especially asparagine, forming melanoid pigments when the product is submitted to high temperatures. Acrylamide, a substance 
considered neurotoxic and carcinogenic with several studies demonstrating a positive association with human cancer (Vinci et al., 2012) is formed concomitantly to the reaction of formation of melanoidines.

On the other hand, the enzymatic darkening is caused by the action of oxidative enzymes, peroxidase (POD) and polyphenoloxidase (PPO), which increase its activity under stress conditions.

The objective of this study was to evaluate the enzymatic changes and carbohydrate metabolism of 'Markies' potato tubers subjected to mechanical damage and exposed to high temperatures before processing.

\section{Method}

\subsection{Plant Material}

Tubers of the 'Markies' cultivar from the producing region of Perdizes, state of Minas Gerais, were planted in June and harvested in October 2016, at 120 days upon reaching the physiological maturation. They were selected according to their size and lack of damage. Wound healing of tubers was carried out at $14{ }^{\circ} \mathrm{C}( \pm 95 \% \mathrm{RH})$ for 10 days. After this period, the temperature was reduced by $1{ }^{\circ} \mathrm{C}$ per day until reaching the storage temperature of $8{ }^{\circ} \mathrm{C}( \pm 90 \% \mathrm{RH})$.

The tubers were stored for 4 months and later divided into control treatment, where the tubers were not harmed; and treatment with damage caused by impact and abrasion caused by the fall of the tubers from 1 meter of height on rough surface, represented by a wall sandpaper number 180 . This process was repeated 10 times for each tuber. After application of the treatments, the tubers were kept on benches at room conditions $\left(28{ }^{\circ} \mathrm{C}\right.$ and $\pm 54 \%$ $\mathrm{RH})$.

The analysis of loss of accumulated fresh mass (FML), total soluble sugars (TSS), reducing sugars (RS), non-reducing sugars (NRS), color of the sticks after frying, polyphenoloxidase (PPO) and peroxidase activity POD) were carried out. The analyses started two hours after the treatments, with a 12-h interval between the evaluations, following the times $0,12,24,36$ and $48 \mathrm{~h}$.

\subsection{Loss of Accumulated Fresh Mass}

The FML was calculated in relation to the initial mass of the tubers and expressed in $\%$.

$$
\mathrm{FML}=100-[(\mathrm{PF} \times 100) / \mathrm{PI}]
$$

where, $\mathrm{FML}=$ loss of accumulated fresh mass (\%); FW = weight of final fresh material on the day of analysis; and IW = weight of the initial fresh material $(\mathrm{g})$ on the day of the experiment.

\subsection{Quantification of Sugars}

The quantification of TSS and RS followed the Phenol-sulfuric method described by Dubois et al. (1956), and the dinitrosalicylic acid (DNS) method described by Gonçalves et al. (2010), respectively. The NRSs were calculated by difference between TSS and RS concentrations and the results expressed in $\%$.

\subsection{Color Classification}

In order to classify the color of the chips, the sticks were fried in an electric fryer with a capacity of $3 \mathrm{~L}$ (Model:

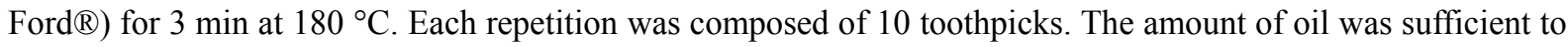
minimize the drop-in temperature after the potatoes were immersed. The color classification of the sticks after frying was visually determined on the basis of a scale of grades, ranging from 1 (extra light) to 5 (brown), according to the standards recommended by USDA through the 'United States Standards for Grades of Frozen French Fried Potatoes' (USDA, 1967), used by the Brazilian potato processing industry.

\subsection{Enzymatic Analysis}

The POD and PPO were determined according to the methodology proposed by Marques (2011) and Kavrayan and Aydemir (2001), respectively, and the results were expressed based on total protein. The protein was evaluated according to Bradford (1976) using bovine serum albumin (BSA) as standard.

\subsection{Statistical Analyzes}

The experimental design was the completely randomized, in the scheme of split-plots. The plots were composed of treatments with and without mechanical damage and the subplots were made up by the evaluation times, with 5 replicates, where the experimental unit was composed of 2 tubers. Data were analyzed through analysis of variance and regression, using the SAEG 9.1 Statistical Analysis System. The regression model was chosen based on the regression coefficients by using the t-test at the $\mathrm{p}>0.05$ probability level, at the coefficient of determination $\left(\mathrm{R}^{2}=\mathrm{SQReg} / \mathrm{SQtrat}\right)$ and the biological behavior under study. 


\section{Results}

Significant differences were observed by the $\mathrm{F}$ test, with interaction between the period and treatments for all variables analyzed, except for percentage of reducing sugars, which obtained influence only of the treatment.

Loss of fresh mass was influenced by the evaluation period, presenting increases of $5.2 \%$ in tubers with damage and $0.6 \%$ in undamaged tubers at $48 \mathrm{~h}$ (Figure 1). This increase reflected in the visual aspect of the tuber that was softened, especially at the site of the injury. Mechanical damage increases respiratory activity and loss of water by exposure of tissues to the environment, facilitating gas exchange and increasing the FML.

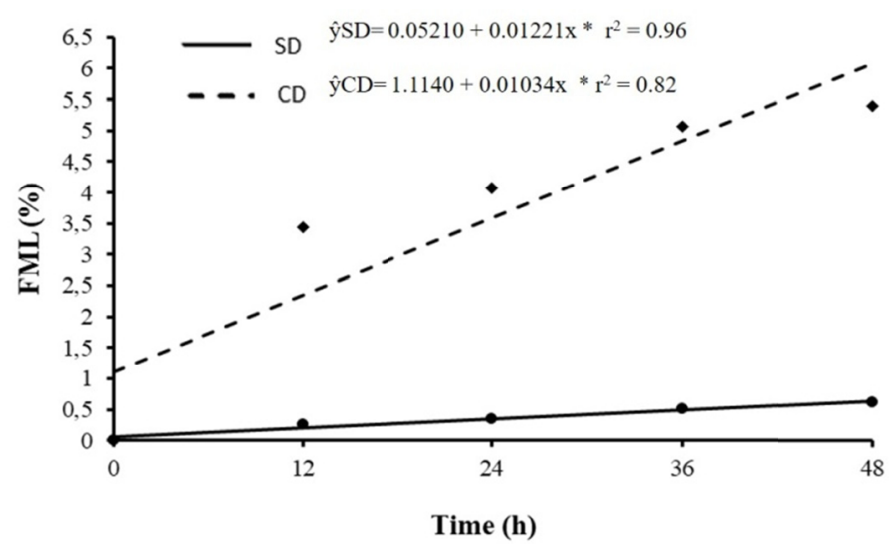

Figure 1. Loss of accumulated fresh mass (FML) in potato tubers cv. Markies without damage (SD) and mechanical damage $(\mathrm{CD})$ at 4 months of storage

Singh and Kaur (2016) state that when potato tubers are placed under storage conditions with temperatures above $15{ }^{\circ} \mathrm{C}$, a sharp increase in respiration occurs, as seen in the present work.

Daniel-Lake et al. (2014) found that the tubers damaged by abrasive damage presented FML $1.7 \%$ greater than control, under storage conditions of $13{ }^{\circ} \mathrm{C}$ and $95 \% \mathrm{RH}$.

The contents of TSS and NRS increased in tubers with mechanical damage reaching 0.29 and $0.25 \%$ at $35.6 \mathrm{~h}$ and $34 \mathrm{~h}$ of storage, respectively (Figures $2 \mathrm{~A}$ and $2 \mathrm{~B}$ ). The mechanical damage promotes the increase in the respiratory rate of the tubers, which induced the activity of starch-degrading enzymes with $\alpha$-amylase, $\beta$-amylase and glycosidase, resulting in the increase of ANRs (Taiz \& Zeiger, 2017) and TSS, as a consequence. 

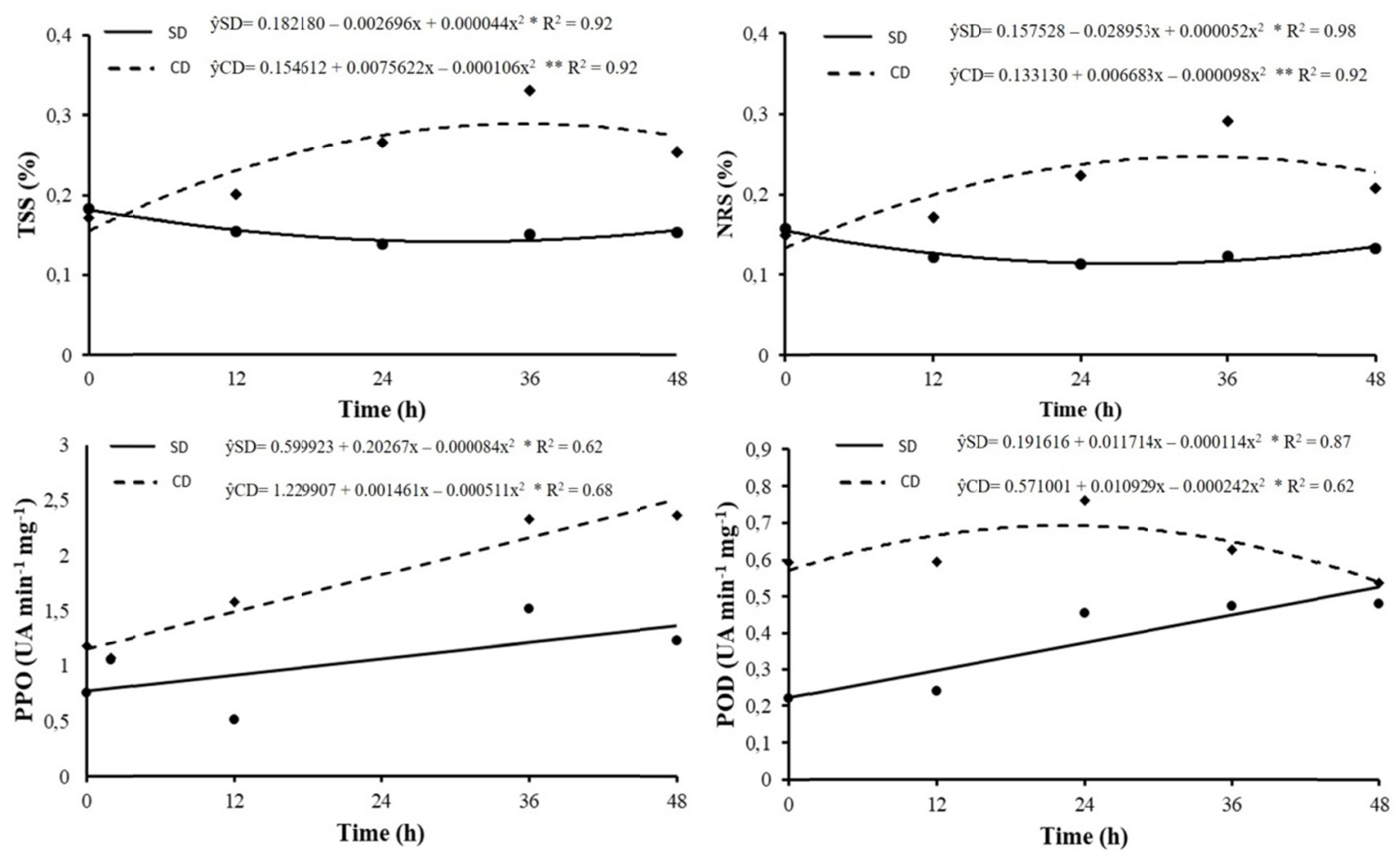

Figure 2. Total soluble sugar (TSS) (A), non-reducing sugar (NRS) (B), activity of polyphenoloxidase (PPO) (C) and peroxidase (POD) (D) in potato tubers cv. Markies without damage (SD) and damage (CD) at 4 months of storage

Regarding control treatment, TSS and NRS had decreases of $0.14 \%$ and $0.12 \%$ in the periods of $30.6 \mathrm{~h}$ and $27 \mathrm{~h}$, respectively, after application of the treatments (Figures 2A and 2B). The reduction in NRS concentration is associated with its use in the respiratory process, since it is considered the primary substrate of plant respiration (Taiz \& Zeiger, 2017). The transfer of the tubers from the refrigerated environment to the room temperature causes an increase in respiratory activity, due to the rise in the temperature, resulting in a rapid consumption of the substrate.

In studies by Strehmel et al. (2010), changes in the primary metabolism of two potato cultivars subjected to mechanical damage were observed, where sucrose showed significant variation in time, with persistent increase between $24-48 \mathrm{~h}$.

The evaluation time did not influence the contents of RS, however, the damaged tubers presented RS concentration of $0.035 \%$, while in the control, and the contents were $0.025 \%$.

The contents of RS and NRS, even with the occurrence of mechanical damage, were adequate for the industry. The levels of RS for potatoes intended for processing should be less than $0.12 \%$ of the fresh mass (Stark et al., 2003), whereas NRS contents should be below $0.33 \%$ of the fresh mass (Chapper et al., 2002). Due to the low concentrations of sugars, the sticks showed a light color after frying and were classified in category 2 . At $36 \mathrm{~h}$, it was possible to observe darkened spots at the ends of the sticks and at $48 \mathrm{~h}, 100 \%$ of the sticks of damaged tubers and $50 \%$ of the sticks. Treatment sticks showed darkening at the tips. Thus, even with the appropriate RS and NRS values, the amino acids and polyphenols may have led to darkening of the tips. However, it did not affect the quality of the product for processing, which proves the recommendation of the Markies variety for the pre-fried potato sector.

Post-fry darkening is determined by the concentration of sugars, amino acids and total polyphenols (Freitas et al., 2006). During frying, reducing sugars, glucose and fructose react with free amino acids through the non-enzymatic browning reaction (Maillard reaction), resulting in dark color and poor quality product (Eriksson, 2005; Knowles et al., 2009).

The PPO activity increased over evaluation time, with less activity (1.41 UA min ${ }^{-1} \mathrm{mg}^{-1}$ protein) in the control tubers, compared to the damaged tubers $\left(2.33 \mathrm{UA} \mathrm{min}^{-1} \mathrm{mg}^{-1}\right.$ protein) (Figure $2 \mathrm{C}$ ). The POD activity increased in 
control, with greater activity at $48 \mathrm{~h}\left(0.52 \mathrm{UA} \mathrm{min}^{-1} \mathrm{mg}^{-1}\right.$ protein $)$, while in tubers with damage increased up to $22 \mathrm{~h}$ (0.69 UA $\mathrm{min}^{-1} \mathrm{mg}^{-1}$ protein), followed by decrease (Figure 2C).

The increase in the activity of these enzymes is a result of the tubers response to oxidative stress situations. In stress condition, it occurs the formation of toxic chemical compounds, such as reactive oxygen species (ROS), inducing the increase in the defense system of the plants to neutralize these molecules.

The increase in POD and PPO activity in tubers with and without damage did not cause darkening before frying, which reinforces the idea that the cultivar Markies is suitable for the processing industry. The PPO in intact potato tuber cells is spatially separated from the phenolic substrates. In the peeling and slicing steps, the cells are broken down, and the PPO starts to convert phenolic compounds to quinones that can polymerize, react with amino acids and form insoluble brown (Treptow et al., 2003), black or gray (Stevens \& Davellar, 1997) pigments The POD acts on the conversion of phenols and on the reduction of hydrogen peroxide (Kao, 2003).

When evaluating the productive efficiency and quality parameters of potato destined to the processing in the form of potato-shoestring straw and chips of nine cultivars of potato Araújo et al. (2016) recommended the Markies cultivar for the industrial processing. Even in the occurrence of mechanical damage and a rise in the temperature, before processing, Markies cultivar remained proper for the industry.

It is concluded that the mechanical damages increase the FML and cause darkening of the tips of the sticks after frying, however this variety still display qualities that are suitable for industrial processing, for maintaining the quality standards required by the processed potato industry.

\section{References}

Araújo, T. H., Pádua, J. G., Spoto, M. H., Ortiz, V. D., Margossian, P. L., Dias, C. T., \& Melo, P. C. (2016). Productivity and quality of potato cultivars for processing as shoestrings and chips. Horticultura Brasileira, 34, 554-560. https://doi.org/10.1590/s0102-053620160415

Bradford, M. M. (1976). A rapid and sensitive method for the quantification of microgram quantities of protein utilizing the principle of protein-dye biding. Analytical Biochemistry, 72, 248-254. https://oi.org/10.1016/ 0003-2697(76)90527-3

Chapper, M., Bacarin, M. A., Pereira, A. D. S., \& Lopes, N. F. (2004). Atividade amidolítica e de invertase ácida solúvel em tubérculos de batata armazenados sob duas condições de temperatura. Horticultura Brasileira, 22, 597-601. https://doi.org/10.1590/S0102-05362004000300019

Daniels-Lake, B., Prange, R., Walsh, J., Hiltz, K., Bishop, S., \& Munro-Pennell, K. (2014). Effects of simulated harvest injury and relative humidity during the first week post-harvest on potato (Solanum tuberosum L.) tuber weight loss during subsequent storage. The Journal of Horticultural Science and Biotechnology, 89, 167-172. https://doi.org/10.1080/14620316.2014.11513064

Dubois, M., Gilles, K. A., Hamilton, J. K., Rebers, P. T., \& Smith, F. (1956). Colorimetric method for determination of sugars and related substances. Analytical Chemistry, 28, 350-356. https://doi.org/10.1021/ ac60111a017

Eriksson, S. (2005). Acrylamide in food products: Identification, formation and analytical methodology (Doctoral thesis, Department of Environmental Chemistry, Stockholm University, Sweden).

Freitas, S. T., Bisognin, D. A., Gómeza, C. S., Sautter, C. K., Costa, L. C., \& Rampelotto, M. V. (2006). Qualidade para processamento de clones de batata cultivados durante a primavera e outono no Rio Grande do Sul. Ciência Rural, 36, 80-85. https://doi.org/10.1590/S0103-84782006000100012

Gonçalves, C., Rodriguez-Jasso, R. M., Gomes, N., Teixeira, J. A., \& Bello, I. (2010). Adaptation of dinitrosalicylic acid method to microtiter plates. Analytical Methods, 2, 2046-2048. https://doi.org/10.1039/ C0AY00525H

Kao, C. H. (2003). Differential effect of sorbitol nad polyethylene glycol on antioxidant enzymes in rice leaves. Plant Growth Regulation, 39, 83-89. https://doi.org/10.1023/A:1021830926902

Kavrayan, D., \& Aydemir, T. (2001). Partial purification and characterization of polyphenoloxidase from peppermint (Mentha piperita). Food Chemistry, 74, 146-154. https://doi.org/10.1016/S0308-8146(01) 00106-6

Keijbets, M. J. H. (2008). Potato processing for the consumers: Developments and future challenges. Potato Research, 51, 271-281. https://doi.org/10.1007/s11540-008-9104-3 
Knowles, N. R., Driskill, E. P. J., \& Knowles, L. O. (2009). Sweeting responses of potato tubers of different maturity to conventional and non-conventional storage temperature regimes. Postharvest Biology and Technology, 52, 49-61. https://doi.org/10.1016/j.postharvbio.2008.08.015

Marques, A. E., Silva, F., Barbosa, J. B., \& Finger, F. L. (2011). Ação de inibidores de enzimas oxidativas e crescimento bacteriano sobre a longevidade das flores de ave-do-paraíso (Strelitzia reginae Aiton). Revista Brasileira de Horticultura Ornamental, 17, 75-86. https:// doi.org/10.14295/rbho.v17i1.720

SAEG. (2007). Sistema para Análises Estatisticas (Version 9.1). Fundação Arthur Bernardes, UFV: Viçosa.

Singh, J., \& Kaur, L. (2016). Advances in potato chemistry and technology (2nd ed.). Academic Press.

Stark, J. C., Olsen, N., Kleink, O. P., Ge, F., \& Love, S. L. (2003). Tuber quality. In J. C. Stark, S. L. Love (Eds.), Potato production systems (pp. 329-343). Aberdeen: University of Idaho.

Stevens, L. H., \& Davelaar, E. (1997). Biochemical potential of potato tubers to synthesize blackspot pigments in relation to their actual blackspot susceptibility. Journal of Agricultural and Food Chemistry, 45, 4221-4226. https://doi.org/10.1021/jf9608837

Taiz, L., \& Zeiger, E. (2017). Fisiologia Vegetal. Porto Alegre: Artmed.

Treptow, R. O., Zorzella, C., \& Vendruscolo, J. (2003). Qualidade sensorial de "chips" de diferentes genótipos de batatas (Solanum tuberosum L.), cultivos de primavera e outono no Rio Grande do Sul. Agricultural Science and Technology, 9, 57-63.

USDA. (1967). United States Standards for Grades of Frozen French Fried Potatoes (p. 16). USDA, Washington.

Vinci, R. M., Mestdagh, F., \& Meulenaer, B. (2012). Acrylamide formation in fried potato products-Present and future, a critical review on mitigation strategies. Food Chemistry, 133, 1138-1154. https://doi.org/10.1016/ j.foodchem.2011.08.001

\section{Copyrights}

Copyright for this article is retained by the author(s), with first publication rights granted to the journal.

This is an open-access article distributed under the terms and conditions of the Creative Commons Attribution license (http://creativecommons.org/licenses/by/4.0/). 